\title{
The Effect of Green Brand Image, Green Advertising and Celebrity Endorsement on Purchase Intention of Green Product
}

\author{
Cynthia Darlius ${ }^{1,}$ Keni Keni ${ }^{1,2 *}$ \\ ${ }^{1}$ Master of Management Program, Universitas Tarumanagara, West Jakarta, DKI Jakarta, Indonesia, 11440 \\ ${ }^{2}$ Faculty of Economics and Business, Universitas Tarumanagara, West Jakarta, DKI Jakarta, Indonesia, 11470 \\ *Corresponding author. Email: keni@fe.untar.ac.id
}

\begin{abstract}
The present study is to analyze the effect of green brand image, green advertising and celebrity endorsement on purchase intention of green product in Jakarta. Descriptive research was done with 262 respondents collected using non-probability sampling with convenience sampling technique but only 191 data were usable to be further processed and analyzed. In this study, all of the data collected from the respondents are using questionnaires with 5-point likert scale for each indicator variables which were distributed electronically and were analyzed using Partial Least Square - Structural Equation Model with SMART PLS 3.2.8 software. The results showed that green brand image, green advertising and celebrity endorsement have a positive and significant effect on purchase intention of green product in Jakarta. In this case green brand image has the biggest effect on purchase intention. The results of this study are expected to provide useful information for companies to be taken into consideration in using green brand image, green advertising or celebrity endorsement to increase purchase intention which also help the companies evaluate and create targeted marketing strategies to increase sales.
\end{abstract}

\section{Keywords: green brand image, green advertising, celebrity endorsement, purchase intention}

\section{RESEARCH INTRODUCTION}

In this era of globalization, changes in people's lifestyle are increasingly felt, followed by the emergence of new industries which are competing to innovate products, increase the amount of production to meet consumer needs and desires. This can result in uncontrolled exploitation of natural resources which can negatively cause the environmental damage. Emissions from waste by-products produced by industry also have a negative impact on the environment and the health of the surrounding community. Excessive use of fossil fuels also results in a greenhouse gas effect that destroys the ozone layer and causes an increase in Earth's temperature. This indicates the emergence of global warming. This phenomenon has led to the emergence of a go green campaign from environmentalists whose role is to expose environmental issues to the public and at the same time create awareness of the importance of green behaviour towards the environment [1].

The demand for environmentally friendly products increases along with increasing concern for the environment in the world, more and more consumers are willing to pay highly to buy green products [2]. The existence of purchase intention for green products encourages companies to compete innovatively in developing environmentally oriented products. In addition, global environmental issues are also used as opportunities for companies to market their products in order to gain an advantage over their competitors [3]. Consumers tend to give positive ratings for environmentally friendly companies. Consumers have a perception that products from a company that come from natural ingredients certainly provide benefits for both themselves and the environment so that consumers are interested in making purchase of these products and other reasons that encourage consumers to make purchases as a contribution to their concern for the environment.

Therefore, it is very important for companies to build consumer awareness of the products offered through promotional activities [4]. In relation to the environment, promotional activities are carried out using environmentally friendly promotional materials, such as recycled bags and through green advertising to influence purchase intention [5]. Green advertising is used to position environmentally friendly products in the minds of consumers [6]. One of the green advertising carried out by companies is by holding a company campaign related to corporate responsibility for the environment. Green advertising can attract consumer attention to focus on the message that used to convey and build consumer awareness of products and company brands that have a commitment to care for the environment. Consumers tend 
to buy products that are beneficial to both themselves and the environment with the perception that everything healthy comes from nature, so the information obtained from green advertising will certainly increase consumer purchase intention of environmentally friendly products. Consumers can easily remember a brand only if consumers have a good perception of the brand [7]. With the uniqueness of the brand image, consumers can assess the quality of a product, reduce purchase risk and obtain satisfaction. If a product has a strong brand image, consumers will immediately rate the product as high quality [8]. The company's green brand image is built in the minds of consumers based on a series of perceptions instilled by the company towards environmental concern [2]. Green brand image that is embedded in the minds of consumers will trigger emotions, attitude and environmentally behaviour from consumers, thereby increasing consumer purchase intention of environmentally friendly products. The company uses a green brand image as a strategy to increase purchase intention for green products [5].

In offering products and to build a brand image that has the ultimate goal of making consumers purchase products, companies often use celebrity figures as advertisements. The effectiveness of using celebrities to introduce company products can be increased by matching the celebrity image with the product personality which will lead to the creation of a strong brand image in the minds of consumers [9]. Celebrity has an attractiveness and credibility that can attract the attention of consumers which will give a good perception of product quality in the minds of consumers. The more famous a celebrity is used to promote a product, the more interested consumers will buy the product and will have an impact on increasing the purchase intention.

Many companies use strategies such as green brand image [3][5][10], green product [11][12][13] and celebrity endorsement [14][15][16] in marketing their products to attract consumers to buy their products as found in some previous study literature. It is undoubtedly important for researchers to conduct further studies to understand how green brand image, green advertising and celebrity endorsement affected on purchase intention of green products.

\section{LITERATURE REVIEW AND HYPOTHESES DEVELOPMENT}

\subsection{Green Brand Image}

Green brand image could be defined as a set of perceptions of a brand in a consumer's mind that is linked to environmental commitments and environmental concern [2]. Furthermore, green brand image could also be understood as a set of perceptions and relations in the mind of the consumer that are connected to its environmental commitments and concerns [5]. Therefore, in this study, green brand image could be understood as a series of consumer perceptions of a company brand that is closely related to its commitment to the environment.

\subsection{Green Advertising}

Green advertising could be defined as a wise marcom strategy, but only if brand marketers have something meaningful to say about ecological efficacy of their brands vis-à-vis competitive brands [17]. Green advertising is also defined as any advertisement that meets one or more of the following requirements: it expresses a positive relationship between a product and the environment; it presents a corporate image of environmental responsibility; or it promotes a green lifestyle, with or without a reference to a specific product or service of the company [18]. In this study, green advertising could be understood as attributes that companies use to convey environmentally friendly message of their products and position them in the minds of consumers.

\subsection{Celebrity Endorsement}

A celebrity earns the audience's trust through the life he or she lives professionally (on the screen, on the sports field, in public office, etc.) and personally, as revealed to the general public via the mass media [17]. The better the celebrity image in the eyes of the community, the higher the public's trust in the celebrity will be and the celebrity will be more idolized. Furthermore, celebrities are defined as individuals who enjoy public recognition and who use this recognition on behalf of a consumer good by appearing with it in an advertisement. The use of celebrities in order to increase the sales and/or the recall value of a brand is called celebrity endorsement [9]. The more popular a celebrity who advertises a product, the more it will attract consumer's attention to buy and try the product that the celebrity is promoting. In this study, celebrity endorsement could be understood as a company's strategy in conveying product information to consumers using celebrity image in order to increase product sales. The use of celebrities in promoting a product can immediately get the attention of consumers and consumers tend to remember the products advertised by celebrities because celebrities have unique interests.

\subsection{Purchase Intention}

Purchase Intention could be defined as the possibility of the consumer making purchase of a product or service [19]. Consumer will make purchases to get what they want. Purchase intention could also be understood as the willingness of an individual to buy promptly or in the near future the advertised product [15]. Consumers who are attracted to an advertisement will have a desire to buy in the near future. The higher the purchase intention, the stronger the consumer's urge to make payments for the product or service he wants to buy. In this study, purchase intention could be understood as a desire that arises from 
within consumers to make purchases in the near future for the advertised product. If the advertisement of a product is more attractive, consumers will be more interested in making a purchase and end with making a payment.

\subsection{The Effect of Green Brand Image on Purchase Intention}

Previous research in Taiwan's LOHAS Club had found that a brand that is positioned in the minds of consumers as an environmentally friendly brand can led consumers to have awareness of the importance of caring for the environment and will make consumers look to brands that have an environmentally friendly image (green brand image) [3]. Emotions and thoughts of consumers on the importance of environmental care also encourage consumers to get involved and make contributions as an act of caring for the environment which leads to an increase in purchase intention to buy environmentally friendly products. This is used by companies to differentiate themselves from competitors by positioning the company's brand image as a company that cares about the environment and the products it sells are safe for consumption and do not endanger the environment in the minds of consumers. A positive assessment from consumers of an environmentally friendly corporate brand image will certainly increase consumers' desire to buy products that are safe for themselves and the environment. Similar results are also found in another study on consumers who have never bought products of The Body Shop in Jakarta and greater area (Jabodetabek) which states that green brand image that is formed in the minds of consumers can affect purchase intention of environmentally friendly products [10]. An environmentally friendly brand image of a product that is formed in the minds of consumers affects consumers attitudes to prefer and buy environmentally friendly products. And another study in Bahawalpur supermarket reinforce previous findings that there is a positive relationship between green brand image and purchase intention [5]. The brand of an environmentally friendly product makes a positive impression on the minds of the public, this leads consumers to buy environmentally friendly products. Based on these studies, the following research hypothesis appears:

\section{H1: Green Brand Image Has a Positive Effect on Purchase Intention.}

\subsection{The Effect of Green Advertising on Purchase Intention}

From a study conducted in Shanghai it was found that green advertising significantly affects consumer purchase intention of environmentally friendly products [11]. Clear and easy-to-understand environmentally friendly advertisements that illustrate the company's sincere concern to the environment are used to inform consumers of the company's commitment to environmental care so that consumers can feel safe and confident about using the company's products and generally consumers who have high concern for the environment will naturally responds to green advertising positively. Positive responses from consumers to green advertising also positively affect consumer purchase intentions of advertised products. Another study in Shanghai found that the communication effectiveness of green advertising is closely related to the attitudes of citizens in the country of origin of product manufacture and consumers who have an environmental orientation [12]. If the country of origin for the manufacture of the advertised product has a positive image and consumers also have a high level of concern for the environment, consumers will show a positive response to the advertisement which makes consumers have a purchase intention of the product. Companies that want to advertise environmentally friendly products should pay attention to the suitability of the image of the country where the product is made and the target consumers so that the advertisements can reach the right target and attract the attention of consumers to like and buy the advertised product. Furthermore, study in Karachi also found that green advertising positively affects the purchase intention of environmentally friendly products [13]. Companies can use environmentally friendly packaging as a medium to convey messages to consumers and make consumers remember the company's brand image. The same results were also found in the research of Bahawalpur supermarket, green advertising expands consumer knowledge about environmentally friendly products and guides consumers to purchase environmentally friendly products [5]. The design of images and writing on green advertising must not only attract the attention of consumers but must also be able to convey the most important message of an environmentally friendly product to consumers in order to increase consumer awareness to buy and consume products that benefit themselves and the environment.

\section{H2: Green Advertising Has a Positive Effect on Purchase} Intention.

\subsection{The Effect of Green Advertising on Purchase Intention}

A study conducted in Abdu Gusau Polytechnic show that the credibility and interest of a celebrity can increase consumer memory of the advertised product brand and have a significant impact on purchase intention [14]. Companies tend to look at celebrities who have a positive image in the eyes of the public in promoting their products. This is because the image of a celebrity greatly affects a product brand, so that if a celebrity is hit by a lopsided issue and gets a negative response from the public, the company will terminate the contract with the celebrity to avoid the negative impact of the celebrity image on the product brand. Further study on Lebanese females also stated that the credibility of a celebrity 
significantly influences consumers in recalling advertisements starring celebrities and having a positive influence on purchase intention [15]. The celebrity image is transferred to the product so that consumers associate the celebrity image with the advertised product. Celebrities have credibility that makes the products they promote more memorable and increases consumer purchase intention of the products. Furthermore, the study on undergraduate students at several east coast and midwestern universities in U.S had found that the attraction of a celebrity in celebrity endorsement has a positive and significant effect on purchase intention [16]. An attractive celebrity will increasingly make consumers remember the product brand being advertised and of course increase consumer interest in buying the product.

H3: Celebrity Endorsement Has a Positive Effect on Purchase Intention.

\section{RESEARCH METHODOLOGY}

The population in this study were consumers of one of the green product brands in Jakarta. The research sample was taken using non-probability sampling with convenience sampling technique. The questionnaire was distributed and filled electronically by the respondents from September 2020 to November 2020 with the criteria of respondents who had purchased the products and were domiciled in Jakarta. The total number of questionnaires collected was 262 respondents, but only 191 data could be used for further analysis. This study uses the variables green brand image, green advertising and celebrity endorsement as independent variables while purchase intention as the dependent variable. The indicator of each variable is measured by a Likert scale with a value of $1-5$ where 1 means "strongly disagree" and 5 means "strongly agree". Regarding the indicator used in this study, a total of 16 indicators explaining 4 (four) different variables were utilized, in which, 5 (five) indicators explaining green brand image variable [2], 3 (three) indicators explaining green advertising variable [5], 4 (four) indicators explaining celebrity endorsement [15] and 4 (four) other indicators explaining purchase intention [5]. Data analysis was performed with Smart PLS 3.2.8 software.

\section{RESULTS \& DISCUSSIONS}

The results of the questionnaire data processing show that the characteristics of the majority of respondents were women $(88 \%)$ with an age range of $21-30$ years $(57.6 \%)$ and work as private employees $(56 \%)$. The majority of respondents' expenses in purchasing skin care products are IDR 300 thousand to IDR 800 thousand per month $(49.2 \%)$ but for green brand products, most, respondents tend to set aside less than IDR 300 thousand per month $(54.5 \%)$ to buy the products with intensity purchases below 2 times a year $(47.1 \%)$. A total of 191 data were analysed using PLS-SEM method in this study. PLS-SEM has an outer model analysis including validity and reliability test and an inner model analysis which includes the coefficient of determination (R-Squared), predictive relevance $\left(\mathrm{Q}^{2}\right)$, effect size $\left(\mathrm{f}^{2}\right)$ and hypothesis testing.

The result from convergent validity test for all variables have AVE value $\geq 0.5$ and the loading factor value of all variables $>0.7$ which means valid [20]. The validity test was also measured based on discriminant validity for Fornell - Larcker, the value of the square root AVE of each variable is greater than the correlation with other variables which means valid [20]. The reliability test for all variables also shows reliable, in which the values of Composite Reliability and Cronbach's Alpha > 0.7 [20]. From this measurement model assessment results, authors conclude that the model and data are valid and reliable. The results are presented on table 1, 2 and 3 .

After all the variables and research indicators meet the valid and reliable requirements, the inner model analysis can then be carried out. This aims to see the estimated strength between the variables to be studied (construct) in order to determine whether the model being built is accurate and strong. The analysis results can be seen on Table 4.

Table 1. Convergent validity and reliability test results

\begin{tabular}{|c|c|c|c|c|c|}
\hline Variables & Denotations & AVE & Factor Loadings & Composite Reliability & Cronbach's Alpha \\
\hline \multirow{5}{*}{$\begin{array}{l}\text { Green Brand } \\
\text { Image }\end{array}$} & GBI.1 & \multirow{5}{*}{0.709} & 0.818 & \multirow{5}{*}{0.924} & \multirow{5}{*}{0.897} \\
\hline & GBI.2 & & 0.884 & & \\
\hline & GBI.3 & & 0.825 & & \\
\hline & GBI.4 & & 0.835 & & \\
\hline & GBI.5 & & 0.846 & & \\
\hline \multirow{3}{*}{$\begin{array}{c}\text { Green } \\
\text { Advertising }\end{array}$} & GA.1 & \multirow{3}{*}{0.795} & 0.902 & \multirow{3}{*}{0.921} & \multirow{3}{*}{0.871} \\
\hline & GA.2 & & 0.892 & & \\
\hline & GA.3 & & 0.881 & & \\
\hline \multirow{2}{*}{$\begin{array}{c}\text { Celebrity } \\
\text { Endorsement }\end{array}$} & CE. 1 & \multirow{2}{*}{0.607} & 0.736 & \multirow{2}{*}{0.860} & \multirow{2}{*}{0.789} \\
\hline & CE. 2 & & 0.755 & & \\
\hline
\end{tabular}




\begin{tabular}{|c|c|c|c|c|c|}
\hline & CE.3 & & 0.841 & & \\
\hline & CE.4 & & 0.781 & & \\
\hline \multirow{4}{*}{$\begin{array}{l}\text { Purchase } \\
\text { Intention }\end{array}$} & PI.1 & \multirow{4}{*}{0.791} & 0.928 & \multirow{4}{*}{0.938} & \multirow{4}{*}{0.912} \\
\hline & PI.2 & & 0.894 & & \\
\hline & PI.3 & & 0.843 & & \\
\hline & PI.4 & & 0.890 & & \\
\hline
\end{tabular}

Table 2 Discriminant validity fornell - larcker result

\begin{tabular}{|c|c|c|c|c|}
\hline Variables & $\begin{array}{c}\text { Celebrity } \\
\text { Endorsement }\end{array}$ & $\begin{array}{c}\text { Green } \\
\text { Advertising }\end{array}$ & $\begin{array}{c}\text { Green Brand } \\
\text { Image }\end{array}$ & $\begin{array}{c}\text { Purchase } \\
\text { Intention }\end{array}$ \\
\hline Celebrity Endorsement & 0.779 & & & \\
\hline Green Advertising & 0.527 & 0.892 & & \\
\hline Green Brand Image & 0.478 & 0.659 & 0.842 & 0.889 \\
\hline Purchase Intention & 0.443 & 0.509 & 0.561 & 0 \\
\hline
\end{tabular}

Table 3 Indicators of each variable

\begin{tabular}{|c|c|c|}
\hline Variables & Denotations & Indicators \\
\hline \multirow{5}{*}{ Green Brand Image } & GBI.1 & $\begin{array}{l}\text { This brand can be considered as a standardized brand that has a } \\
\text { commitment to the environment }\end{array}$ \\
\hline & GBI.2 & This brand maintains a professional reputation for environmental care \\
\hline & GBI.3 & $\begin{array}{l}\text { This brand is considered successful in its performance of caring for the } \\
\text { environment }\end{array}$ \\
\hline & GBI.4 & This brand is well known for its environmental care \\
\hline & GBI.5 & This brand is believed to be able to fulfill its environmental promises \\
\hline \multirow{3}{*}{ Green Advertising } & GA.1 & $\begin{array}{l}\text { This brand is advertising enhances my knowledge of environmentally } \\
\text { friendly products }\end{array}$ \\
\hline & GA.2 & I enjoy this brand ad that carries an environmentally friendly concept \\
\hline & GA.3 & $\begin{array}{l}\text { Eco-friendly product advertisements of this brand provide information that } \\
\text { guide me to purchase the products. }\end{array}$ \\
\hline \multirow{4}{*}{ Celebrity Endorsement } & CE.1 & Celebrities in this brand commercials are well-known celebrities \\
\hline & CE. 2 & The celebrities in this brand commercials have pretty face \\
\hline & CE.3 & I believe in this brand products that are advertised by celebrities \\
\hline & CE.4 & $\begin{array}{l}\text { I believe the celebrities advertising this brand products have experience } \\
\text { using the products }\end{array}$ \\
\hline \multirow{4}{*}{ Purchase Intention } & PI.1 & I intend to buy this brand products \\
\hline & PI.2 & I am willing to buy this brand products \\
\hline & PI.3 & I tend to buy this brand products \\
\hline & PI.4 & I have a high intention to buy this brand products \\
\hline
\end{tabular}


Table 4 Path coefficient and hypotheses testing results

\begin{tabular}{|c|c|c|c|c|c|}
\hline Hypothesis & $\begin{array}{c}\text { Path } \\
\text { Coefficient }\end{array}$ & t-value & Sig. Value & Results & $\begin{array}{c}\text { Assessment } \\
(\mathbf{p}<\mathbf{0 . 1 0})\end{array}$ \\
\hline $\begin{array}{c}\text { H1: Green Brand Image has a Positive } \\
\text { Effect on Purchase Intention of } \\
\text { Green Product in Jakarta. }\end{array}$ & 0.358 & 4.421 & 0.000 & Significant & H1 Supported \\
\hline $\begin{array}{c}\text { H2: Green Advertising has a Positive } \\
\text { Effect on Purchase Intention of } \\
\text { Green Product in Jakarta. }\end{array}$ & 0.180 & 1.944 & 0.052 & Significant & H2 Supported \\
\hline $\begin{array}{c}\text { H3: Celebrity Endorsement has } \\
\text { a Positive Effect on Purchase } \\
\text { Green Product in Jakarta. }\end{array}$ & 0.178 & 2.475 & 0.014 & Significant & H3 Supported \\
\hline
\end{tabular}

In the inner model analysis stage, the results of the RSquared found that green brand image, green advertising and celebrity endorsement had a combine effect of $37.1 \%$ in affecting purchase intention, while $62.9 \%$ was influenced by other variables outside the boundaries of this study. Furthermore, it also found that $\mathrm{Q}^{2}$ value of 0.269 was greater than 0 , it illustrates the all variables in this study could well-predicted the research model. As addition, the effect size test is carried out in order to determine the effect of a variable as a predictor of the research model by inserting or eliminating certain variables from the research model. The result found that the green brand image has a predictor level of 0.111 on the purchase intention variable and gives the greatest predictor effect on changes high and low of the purchase intention while the other variables, green advertising has a predictor level of 0.026 dan celebrity endorsement has a predictor level of 0.035 on purchase intention variable.

Meanwhile, in this study the hypothesis testing was carried out using two-tailed t-value of 1.65 with significance level of $10 \%$. The results presented on table 4 concluded that all hypothesis was supported in this study. The first hypothesis formulates that green brand image had a positive effect on purchase intention of green product in Jakarta. With path coefficient value of 0.358 (positive) and significance value of $0.000(0.000<0.1)$, it could be concluded that the results of this hypothesis was significant and ensuring H1 supported. Furthermore, the second hypothesis formulates that green advertising had a positive effect on purchase intention of green product in Jakarta. With path coefficient value of 0.180 (positive) and significance value of $0.052(0.052<0.1)$, it could be concluded that the results of this hypothesis was significant and ensuring $\mathrm{H} 2$ supported. Finally, the third hypothesis formulates that celebrity endorsement had a positive effect on purchase intention of green product in Jakarta. With path coefficient value of 0.178 (positive) and significance value of $0.014(0.014<0.1)$, it could be concluded that the results of this hypothesis was significant and ensuring H3 supported. Therefore, authors concluded that all of the hypotheses formulated in this study were supported.

The research result from $\mathrm{H} 1$ supported indicates that the better the green brand image that is formed in the minds of consumers, the more power it will have to encourage consumers to be involved in caring for the environment. Based on the findings above, it can be concluded that this green brand has succeeded in instilling a green brand image in the minds of consumers as an environmentally friendly brand that leads consumers to have awareness of the importance of caring for the environment. The design of the logo and brand name in green, outlets decorated with green leaves and the name of the product on the packaging using the name of the natural material used in the manufacture of the products makes consumers perceive that this product comes from natural ingredients are safe for consumption and the environment. This good perception will lead to increased consumer purchase intention of green product.

Furthermore, the research result from $\mathrm{H} 2$ supported indicate that the design of images and writing on green advertising that is made more attractive and able to convey the most important message of an environmentally friendly product to consumers can increase consumer awareness of buying and consuming products that benefit themselves and the environment. Based on these findings, it can be concluded that this brand green advertising through green forest campaign and providing rewards points for consumers who return empty product packaging has succeeded in attracting consumers' attention to green products. With the presence of informative green advertising, will increase consumer awareness of the brand that is environmentally friendly and guide consumers to buy green products.

Moreover, the research results from $\mathrm{H} 3$ supported indicate that the image of a celebrity greatly affects a product brand. The celebrity image is transferred to the product so that consumers associate the celebrity image with the advertised product. Celebrities have credibility and attractiveness that makes the products they promote more memorable and increases consumer purchase intention of the products. Based on these findings above, it can be concluded that the celebrity who promotes the brand is a famous celebrity who is recognized as having a beautiful face so that it is suitable to represent the products. The celebrity has a good image in public's eye so that she has credibility to attract consumer's attention and provide a good perception of this brand product quality in the minds of consumers so that consumers are interested in buying the products. 


\section{CONCLUSIONS \& IMPLICATION}

Based on the results obtained on this study, authors concluded that green brand image, green advertising and celebrity endorsement have a positive and significant effect on purchase intention. In addition, the results of the study also found that the green brand image variable was the biggest predictor of the changes high-low of purchase intention.

In regard with these conclusions, company in order to improve its green brand image that has been successfully embedded in the minds of consumers, need to maintain their reputation for caring the environment professionally by reducing plastic packaging waste for their products which can be realized by innovating in making new packaging and shopping bags from food waste such as dry grain, soybean shells and peanut shells. This innovation in new packaging can also differentiate the company from other companies because it is considered unique and consumers will have a good perception of the company's brand so that it will further increase purchase intention of the company's products.

Besides using green forest campaign and empty bottle recycling campaign, companies can also hold creative activities with the community using empty bottle packaging, which in turn will increase micro, small and medium enterprises (UMKM) as well. With the existence of concrete actions that can be felt by the general public and consumers, it can increase consumer trust and increase the company's brand image that is environmentally friendly in the minds of consumers. Furthermore, consumers will be increasingly interested in buying company products, which will lead to an increase in purchase intention.

Company can choose well-known celebrities who have a good image in public's eyes. In terms of increasing consumer confidence that celebrities have experience using company products, the authors suggest that celebrities who advertise products do not advertise other brand products even though the celebrity contract period that advertises company products was over. This is useful for increasing consumer confidence in company's products and maintaining a positive image in the minds of consumers so that consumers are interested in buying products.

\section{LIMITATIONS \& SUGGESTIONS FOR FUTURE RESEARCH}

The research carried out is inseparable from limitation. First of all, the results of this research which was conducted in Jakarta would certainly be different if the same research was conducted in other cities. Therefore, further research regarding this topic should conduct in the other regions of cities in Indonesia. Second, other variables or additional factors that influence consumer's purchase intentions that have not been studied in this study can be selected to be studied in the future in order to gain new insight from the research results obtained. Moreover, the results of this study may be different if the majority of respondents have different characteristics, such as research conduct at a certain age range only or go-green lovers.

\section{ACKNOWLEDGMENT}

The authors would like to appreciate the LPPM, the Institution for Research and Community Service of Universitas Tarumanagara (Lembaga Penelitian dan Pengabdian kepada Masyarakat Universitas Tarumanagara) for financial support with contract No. 1638-IntKLPPM/Untar/XII/2020. Authors also would like to express his/her sincere gratitude to Dr. Keni, S.E., M.M. as a supervising lecturer who gave encouragement to join in this research, and for the instruction, advice, suggestions for authors in the completion of this paper. Furthermore, the authors would like to thank all of the respondents who are willing to take their time to fill out the online questionnaire and to Dr. Indra Widjaja, S.E., M.M. as Head of Master of Management Program Universitas Tarumanagara who has provided the opportunity for authors to study and conduct this research. Thanks to all lecturers and those who contributed directly or indirectly in completion of this paper.

\section{REFERENCES}

[1] Islam, M.R., Saidur, R., Rahim, N.A. and Solangi, K.H., Usage of solar energy and its status in Malaysia, Engineering E-Transaction Journal, 5(1), 2010, pp. 610.

https://www.researchgate.net/publication/233936813_U sage_of_solar_energy_and_its_status_in_Malaysia

[2] Chen, Y.S., The drivers of green brand equity: green brand image, green satisfaction, and green trust, Journal of Business Ethics, 93(2), 2010, pp. 307-319. https://doi.org/10.1007/s10551-009-0223-9

[3] Huang, Y.C., Yang, M. and Wang, Y.C., Effects of green brand on green purchase intention, Marketing Intelligence \& Planning Journal, 32(3), 2014, pp. 250268. https://doi.org/10.1108/MIP-10-2012-0105

[4] Bhalerao, V.R. and Deshmukh, A., Green marketing: green the 4Ps of marketing, International Journal of Knowledge and Research in Management \& E-Commerce, $\quad 5(2), \quad 2015, \quad$ pp. 5-8. 
https://www.researchgate.net/publication/310345086_G reen_Marketing_Greening_the_4_Ps_of_Marketing

[5] Rizwan, M., Mahmood, U., Siddiqui, H. and Tahir, A., An empirical study about green purchase intentions, Journal of Sociological Research, 5(1), 2014, pp. 290305. https://doi.org/10.5296/jsr.v5i1.6567

[6] Eren-Erdogmus, I. , Lak, H.S. and Çiḉek, M., Attractive or credible celebrities: who endorses green products better?, Social and Behavioral Sciences, 235, 2016, pp. 587-594. https://doi.org/10.1016/j.sbspro. 2016.11.085

[7] Khan, I., Majeed, S. and Ghauri, T.A., Impact of brand related attributes on purchase intention of customers a study about the customers of Punjab, Pakistan, Interdisciplinary Journal of Contemporary Research in Business, 4(3), 2012, pp. 194-200. https://www.researchgate.net/publication/261983504_I MPACT_OF_BRAND_RELATED_ATTRIBUTES_O N_PURCHASE_INTENTION_OF_CUSTOMERS_A_ STUDY_ABOUT_THE_CUSTOMERS_OF_PUNJAB _PAKISTAN

[8] Khan, N., Hamed, S., Rahmani, R., Yong, H.H. and Chen, T.B., Causal relationships among dimensions of consumer-based brand equity and purchase intention: fashion industry, International Journal of Business and Management, 10(1), 2015, pp. 172-181. https://doi.org/ 10.5539/ijbm.v10n1p172

[9] Koshy, L. and Manohar J., Influence of celebrity endorsement on brand image of grooming products, SSRN Electronic Journal-id2969781, 2017, pp. 1-12. https://doi.org/10.2139/ssrn.2969781

[10] Aulina, L and Yuliati, E., The effects of green brand positioning, green brand knowledge, and attitude towards green brand on green products purchase intention, Advances in Economics, Business and Management Research, 36, 2017, pp. 548-557. https://doi.org/10.2991/icbmr-17.2017.50

[11] Zhu, B., The impact of green advertising on consumer purchase intention of green products, Proceedings of World Business and Economics Research Conference 2012, Available at SSRN: https://ssrn.com/abstract=2182906

[12] Chan, R.Y.K. and Lau, L.B.Y., The effectiveness of environmental claims among Chinese consumers: Influences of claim type, country disposition and ecocentric orientation, Journal of Marketing
Management, 20(3-4), 2004, pp, 273-319. https://doi.org/10.1362/026725704323080425

[13] Ansar, N., Impact of green marketing on consumer purchase intention, Mediterranean Journal of Social Sciences, 4(11), 2013, pp. 650-655. https://doi.org/ 10.5901/mjss.2013.v4n11p650

[14] Apejoye, A., Influence of celebrity endorsement of advertisement on students' purchase intention, Journal of Mass Communication and Journalism, 3(3), 2013, pp, 1-7. https://doi.org/10.4172/2165-7912.1000152

[15] Hani, S., Marwan, A. and Andre, A, The effect of celebrity endorsement on consumer behaviour: case of the Lebanese jewelry industry, Arab Economics and Business Journal, 13(2), 2018, pp. 190-196. https:// doi.org/10.1016/j.aebj.2018.11.002

[16] Till, B.D. and Busler, M., The match-up hypothesis: physical attractiveness, expertise, and the role of fit on brand attitude, purchase intent and brand beliefs, Jounal of Advertising, 29(3), 2013, pp. 1-13. https://doi.org/10.1080/00913367.2000.10673613

[17] Shimp, T.A. and Andrews, J.C., 2013, Advertising, Promotion, and Other Aspects of Integrated Marketing Communication $9^{\text {th }}$ ed., USA: Cengage Learning. https://www.cengage.co.uk/books/9781111580216/

[18] Wagner, E.R. and Hansen, E.N., 2002, Methodology for evaluating green advertising of forest products in the United States: a content analysis, Forest Products Journal, 52(4), 2002, pp. 17-23. https://www. researchgate.net/publication/258561254_Methodology_ for_Evaluating_Green_Advertising_of_Forest_Products _in_the_United_States_A_Content_Analysis

[19] Jundrio, H. and Keni, K., Pengaruh Website Quality, Website Reputation dan Perceived Risk Terhadap Purchase Intention Pada Perusahaan Ecommerce. Jurnal Muara Ilmu Ekonomi dan Bisnis, 4(2), 2020, pp. 229-239. https://doi.org/10.24912/ jmieb.v4i2.7802.

[20] Hair, Jr J., Hult, G., Ringle, C. and Sarstedt, M., 2017, A Primer on Partial Least Squares Structural Equation Modeling (PLS-SEM) $2^{\text {nd }}$ ed, Los Angeles: SAGE Publications, Inc. https://us.sagepub.com/enus/nam/a-primer-on-partial-least-squares-structuralequation-modeling-pls-sem/book244583 